
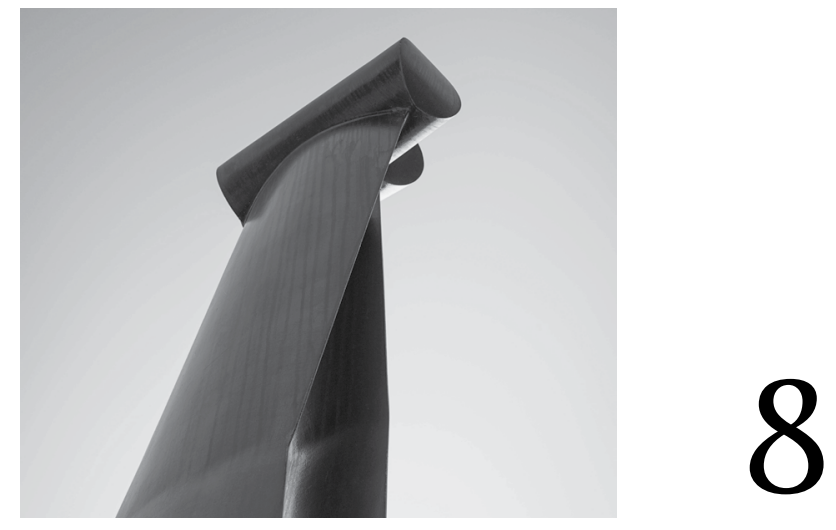

\title{
SEMANTICS IN THE PHILOSOPHY OF RACE
}

\author{
George Chaplin and Nina G. Jablonski
}

The three Questions: The problem of racial thinking

The three questions that framed the discussions of the Effects of Race Project in 2017 were, "What do you not like about race and racial thinking? "Why?" And "How would you fix it?" What we dislike most about race is its enduring and tenacious nature. This is despite the fact that it has been discredited by many scholars and constituencies and shown to be not useful. Race is an historical contingency, not a state of nature. Anthropologists see the commonality of humankind and a legacy of widely shared cultural and physical traits that outweigh any differences that may exist. The tenacity of race has made it possible for racism, its handmaiden, to grow and endure. Race has so co-opted our consciousness and language that it has made any attempt to deal with the effects of racism very difficult.

The addictiveness of racial thinking thwarts all attempts to unite humanity into a common cause. Philosophers are divided in their attitudes, with some preferring to split and others preferring to unite, but logically both attitudes can be defended. 
New attempts to erect race constantly arise based on economic, educational, biological, and most recently genetic grounds (El-Haj, 2007; Long, Li \& Healy, $2009 \mathrm{~b}$ ). This is despite the overwhelming commonalities of biology, culture (such as the universal love of music, dance, and ritual), social organisation, kinship structures, language, and spirituality which render minor differences and any subdivisions based on them meaningless (Relethford, 2009; Soudien, 2012).

What can be done about this enduring race ideology? We need to change the discourse by changing the lexicon. Language space is constantly changing, however, and semantic meanings reinforce past preconceptions and prejudices. This is because the innate structure of the brain and its pathways ensures that there is no negation in the subconscious. Reusing past pejoratives in new contexts will not remove their meanings, but only add to them. The name-space of race is so crowded that even neologisms with no past connections or meanings are hard to derive, but a new vocabulary is what is needed.

\section{Introduction}

The Western idea of real races, in a biological sense, was questioned at its start as being anti-biblical because it required there to have been separate creations (Sussman, 2014). Racialism and racism rose in the service of slavery and economic exploitation (Jablonski, 2012a; Samson, 2005). Generally, since the United Nations' (UN) Statement on Race (UNESCO, 1952) the acceptance of biological race has been in a very slow decline and had become almost universally moribund in scientific circles. Fairly recently, however, some philosophers, geneticists, and those in the medical professions have repeatedly tried to resurrect biological definitions of race (Bamshad, Wooding, Salisbury \& Stephens, 2004; Lee, Mountain \& Koenig, 2001; Wade, 2002). On the other hand, sociologists and the general public recognise that the idea of race, and its concomitant racism, is still a real phenomenon (Graves, 2015). If for no reason other than to recognise the reality of race in the social realm, we need to speak about it. The idea that racialism and racism will go away with non-discussion is nonsensical and wishful. Some favour the preservation of named races because they make it easier to preserve unity and a positive social identity amongst people who are or were oppressed. Those with an attachment to the idea of biological races see it as having some utility, perhaps as a shorthand for nested biological facts (Chaplin, 2018). Others seem to believe that if biological race is shown to be real, people will accept it and move on, or use supposed biological race to justify racial separatism as practiced by neo-Nazis.

Racial thinking is not just a metaphysical problem, it is a semantic one too. The language around race has been fully occupied and is nearly universally derogatory and hurtful. Neologisms like "people of colour" arose in the 1930s after "coloured 
people" became restricted to mean African American people in the United States, and again at the end of the twentieth century in an attempt to be inclusive of groups of people identified as non-European light skin. Basically, people of colour who designated the set included all non-white people who were subjected by the white dominant culture. Race is not always imposed on people, but is often willingly embraced. The economically powerful see race as a shorthand for class, intelligence and ability, and biology. The economically disadvantaged see it as a cause of their suffering and as a uniting principle. To both sides, it is a factor used to justify an Us-Them dichotomy. A similar phenomenon is observed in the use of regional dialects and accents in homogenous peoples where the upper class impose their perceived pronunciation on the lower classes and the lower classes cling to their accents. Therefore, the subjugated are not free from the support of racialised thinking, any more than Cockney speakers or people with Brooklyn accents are free from class discrimination. Thus, the Us-Them divide is often a two-way street, and the less advantaged of the two sides often don't help themselves by supporting the discriminatory status quo.

\section{Race labels and hate speech}

One effort has been to usurp hateful speech by the subjugated people themselves. A non-racial example would be "queer", a once very derogatory term for people who prefer partners of the same gender as themselves. Redeployment of the word as a positive identifier has been somewhat successful at lessening its broader impact as a slur. Within the queer community, the adoption of the "queer" has repurposed the term to be inclusive and accepting. The name is still used as marker of Us-Them, as in queer studies departments, and so still harkens back to the days of an Us-Them sexuality divide. In defeating homophobia, the neologism "gay" has been much more effective at heading-off discrimination. Within a few decades, "gay" has entered the lexicon of normative life. The acceptance of non-binary sexuality was greatly facilitated by the appropriation of a simple upbeat word. It has been remarkable that the once widespread public acceptance of homophobic speech within the United States is now seen as harmful and anachronistic (Watson, 2017), and is restricted to certain pseudo-religious political movements. In private, homophobic speech is still found within the more isolated, poorly educated, and economically depressed parts of society. It seems that today the acceptance of gay people is the norm and their rejection is the exception. This is a dramatic difference since the Stonewall riots of 1969, which can be seen as the start of the gay rights movement. Before then, non-homophobic people would routinely use the slurs popular with the bigoted. In places like San Francisco, even the label of "gay" is losing its power as the different sexual persuasions are now so normalised 
that there is no need to label people by their orientation. The mere absence of derogation, however, does not mean things are moving forward; it marks the beginning of that process.

There has been a similar attempt to appropriate racial hate-speech to lessen its power and unite its victims. In race speak, the hate-term, "nigger", which had previously only derogatory and disparaging connotations, has been co-opted by the very people it was applied to as their own neologism (Croom, 2011, 2013). It has been redefined in modern usage and sometimes modified slightly, for example, "nigga" of hip-hop and rap, as an empowering collective noun, usable only by the people to whom the term applies. This has created a lexicon of limited unity, centred on negativity, exclusivity, and division. The use of this term by those not in the inner circle of the term's reference - and probably not of the same race - is still seen as carrying its original meaning to those in the inner circle and by a large percentage of those outside too. Today, use of the word in its original context, with vehemence, is socially unacceptable and, for a public figure, career-ending. Use it in its neologistic sense, in the context of rap, requires mitigation by extensive apologies unless it is used by someone in the inner circle as an inclusive term about a shared experience. Peter Vecsay, a white sportscaster, was told not to use racial epithets applied to LeBron James when reporting a basketball game, even if he was only quoting a popular rap song (Watson, 2017). An even greater controversy arose over American late-night talk show host and comedian, Bill Maher, telling a racially charged joke using the "N-word". To quote rapper Ice Cube talking about the term as used by Bill Maher, "That word is like a knife", he said. "You can use it as a weapon or you can use it as a tool. It's been used as a weapon by white people, and we're not gonna let it happen again. That's our word now", Ice Cube continued. "And you can't have it back" (Thompson, 2017). To Ice Cube, it is a tool, but as he further pointed out, Bill Maher was not sounding funny, "Sometimes you sound like a redneck trucker". Here, Ice Cube seems to be acknowledging that many users of the term today have not given the semantic meaning originally associated with the word and continue to endorse its derogatory meaning. Even official race labels like the apartheid-era "black" and "coloured," as used in South Africa, have both descriptive and derogatory meanings, because, repurposing the terms of racism has not seen the power of the words diminish that much. Rather, repeating terms of racial discrimination has just added a layer of further confusion. Any reuse of a semantic term in race-thinking and racialism is not only laden with meaning, it reifies all its previous meanings. This is because, and this cannot be emphasised enough, there is no negation in the subconscious, only re-affirmation.

Besides the terms of race-hatred, even official race labels like "black" and "coloured" still used in South Africa have both descriptive and derogatory meanings, because, 
repurposing the terms has not seen their power diminish significantly (Maré, 2000, 2011). Any reuse of a race term in the service of race-thinking and racialism is not only laden with meaning, but it reinforces all its previous meanings and connotations. This greatly complicates race studies and the discussion of racethinking. Almost every effort to use race neutral terms has failed because the depauperate lexicon has already been exhausted.

It is difficult to find or create neologisms which are defined and widely understood without being descriptive or pejorative. "Gay" has served successfully for homosexual communities, and it would be ideal if a comparably upbeat and unifying term could be created or co-opted to describe former races. If one can be found that would be as successful as "gay" has been, it would be very helpful at defeating racism. Just like gay does not harp on the past discrimination, but rather promotes the group of people in uplifting terms, then any racial neologism should not be restrictive or hark back to previous slights, discrimination, and subjugation. Any effective neologism must arise from, and be acceptable to, the community to which it applies. A neologism is unlikely to be a panacea, but for it to be useful its usage cannot be restricted, limited in meaning, or confined to an inner circle supporting the Us-Them divide. Therefore, any successful neologism for defeating racism must be widely acceptable to, and universally applied within, the community that it applies to, and it must arise from within that community.

The deconstruction of race has been mostly successful in scientific circles, to the extent that it is widely accepted that the biological basis of race is without foundation, with the result that most basic biological and social scientists have rejected the concept (Graves, 2003, 2015; Soudien, 2020). This has not resulted in the abandonment of race labels in society, however. The deconstruction of race by scientists has not been accepted outside of scientific and some academic circles. Feelings and opinions about race exist in countries with past histories of legislated segregation like the United States and South Africa, even though race labels have lost all formal legitimacy (Maré, 2000). In these places, animus towards people belonging to races other than "one's own" remains and is often manifested at home or amongst others with shared attitudes, a process Maré refers to as the "privatization of race" (2000). The use of pejorative labels and epithets is illegal, but the racism persists, albeit cloaked and only privately revealed (Jablonski, 2012b). At present in the United States, the removal of some of the opprobrium towards openly racist attitudes has seen a resurgence of publicly displayed race hatred and neo-Nazi activity. This has shocked the deconstructionists of race and has shown that the imposition of science-based ideas about the biological un-reality of race is unlikely on its own to prevent racialisation, race-based derogatory discourse, and flat-out hate speech. Biological conceptions of race that linger in the popular 
imagination provide justification for a racially inequitable status quo and for continued social marginalisation of historically disadvantaged groups (Williams \& Eberhardt, 2008). The resurgence of publicly displayed race hatred is also occurring because it is seen to be tacitly authorised or condoned. Deeply held beliefs about the biological reality of race along with blatant racism previously suppressed out of fear of disapproval or legal action are now made public. This is because most people believe that race is a real biological fact.

\section{The ontological status of race as a biological fact}

The deconstruction of race has been mostly successful in science circles, to the extent that the biological basis of race is without foundation and most basic biological and social scientists have rejected the concept (Eberhardt, 2005; Eberhardt \& Randall, 1997; Relethford, 2009). The deconstruction of race by scientists has not been accepted widely outside of specific academic circles, however. The removal of some of the opprobrium towards racism in the United States under the current administration, has witnessed a resurgence of openly displayed race hatred and neo-Nazi activity. This has shocked race deconstructionists and has shown that science imposed from outside is unlikely on its own to prevent racialisation, race-based derogatory discourse, and flat-out hate speech. This is because most people believe that race is a real biological fact, and deeply held beliefs previously maintained completely in private are being aired publicly because they have been tacitly authorised. In other words, the deeply held beliefs about the biological reality of race were only suppressed out of fear of disapproval or legal action. This trend is also indicative of a deep distrust of science amongst the general public in the United States borne of the belief that science is not about the discovery of facts, but is a politicised belief system. However, the semantic intent of race as a metaphysical biological reality has been overridden by better understanding of biology and genetics (Graves, 2015; Long \& Kittles, 2009a).

If race is to stand as a biological fact, and for it to have an ontological standing as such, it should only be defined by a biological meaning. This does not stop people from adding contemporary ideas such as biogeography to make new racial terms, or to redefining and reinscribing old terms (Spencer, 2015). This has been done in reaffirming the reality of the United States Census categories according to or as coincident with reconceptions of Blumenbach's continental race groupings (Spencer, 2009). ${ }^{1}$ These reconceptions rely on ideas of within-species

1 The United States Census website states: "What is race? The Census Bureau defines race as a person's self-identification with one or more social groups. An individual can report as White, Black or African American, Asian, American Indian and Alaska Native, Native Hawaiian and Other Pacific Islander, or some other race. Survey respondents may report 
variation being developed as geographic isolates. In biological speciation theory, geographically restricted populations evolving in isolation is a major cause of subspecies arising and new species developing. That is, given some long period of isolation and further differentiation there would arise subspecies and rising eventually to the level of a separate species. Is this what is of expected of humans? Geography is not biology though. Humans have always been mobile, and few instances of true population isolation without migration or gene flow have ever been identified. Differences in skin colour are adaptions to different ecological (solar) circumstances, but these differences do not describe trophic-level sub-speciation as in ecological speciation models. Therefore, at no time has Homo sapiens been a species with separate subspecies on the way to becoming multiple new species. Despite this, the concept of population isolation is the central tenet of race purity laws. The concept fuels the propagation of beliefs about miscegenation, and of race mixing leading to genetic degradation, that are favoured by far-right and neo-Nazi groups. This is the belief that selection on human variation is eliding deleterious genes to promote a Nietzschean übermensch within one single ecological or geographic isolate. Originally, there was one pair of humans, who had evolved from other near-humans in the ancestral line. Races are never ancestral but always develop later from within-species variation working through other factors. Humans are, and have always been, a single species and they must remain so as people become ever more admixed and gene flow over long distances continues.

Species as a metaphysical reality are individuals (Ghiselin, 1997). They can be described but not defined. They are not a class or a set or a kind. Species are real individual things, but subspecies are never that. Races or biological isolates, genetic groupings, natural geographic populations, a group, a defined class, a set, are biologically subspecific entities and have no metaphysical individual reality (Ghiselin, 1997). These can be defined and are always specific to a temporally and semantically contingent usage. The United States Census categories are defined by the Bureau of the Census and their definitions changes with time and are only understood clearly by the people of the time and place where the usage is understood, even if the majority think they clearly understand the terms. Everyone who thinks of race applies a biological definition to it and, in addition, applies geographic/social/ethnic definitions used to further refine the term. Biology is always present in such conceptions because race is a quasi-taxonomic idea.

multiple races. What is ethnicity? Ethnicity determines whether a person is of Hispanic origin or not. For this reason, ethnicity is broken out in two categories, Hispanic or Latino and Not Hispanic or Latino. Hispanics may report as any race." These definitions are not exclusive and do not map easily to continents (Blumenbach, 2000; Spencer, 2009). 
No matter how we define species, as a cladistics species of common descent (Kluge \& Wolf, 1993), a biologically isolated non-interbreeding individual thing, or an idealised abstract individual thing, they all have the commonality of individuality (Ghiselin, 1997). Mere lists of characters are the phenotype, and the idea of a phenetic species definition was long abandoned as unstable and non-exclusive and not an individual. The species must be unique and is never defined by membership in a class or a set (Ghiselin, 1997). This is never true of variation within a species. A local geographic grouping of members of a species (or a deme) is always temporally contingent. Given enough time, the variant population will either merge back with the greater population it emerged from, or will become specialised or drift away from the mean so as to be no longer a variant but something definite and individual of itself. Races will disappear or become further differentiated with time. There is no realism or antirealism with respect to races, they are defined unstably to suit an end and have no enduring metaphysical standing. Any essentialism or typologies have stasis as their underlying emphasis and privilege stasis over change. Essentialism shows something to be real and immutable like a real number or pi which has essence even if not fully innumerable. In discussions of species, essentialism is often thought of as an archetype. So, if a race was an immutable Aristotelian thing, it could not be changing by definition, neither geographically or historically. We should not be able to confuse the properties and the parts of a race if they are describing a real thing. Populations are always interdependent on their members, whereas, an individual is not interdependent with another individual or with a group. The concept of a population in genetics is not as an Individual but as a class or a group and as such a population; therefore, population is never stable and is always changing the frequencies of its various genetic components. If we were to take complete genomes instead of arbitrary chosen genes, then each individual would be just an individual. If we take the complete genomes of all the variants within a species, it too would be an Individual thing encompassing all the variation but not identical to any other species. This is again not true with subspecies.

The null hypothesis for race definition, race-thinking, or racialism must be that humans are one species, not that races are real in any metaphysical sense. Before there can be race deniers, there have to be race affirmers. The affirmers of race have not yet shown race to be biologically real. The human species is an Individual and does exhibit variation and other properties, but these are temporarily contingent and open to various almost infinite definitions. These definitions are chosen for a purpose. They are said to have utility for that purpose. It is beyond metaphysics to say that the purpose is valid only whether it is not real or not. Race not being an individual thing like a species is only ontologically sound if the definition is spelled out on for each occurrence the term is invoked. This never happens. Therefore, people say they know race when they see it: race is so flexible and inclusive that 
everyone can see it how they want. When they try to put that into words, the semantic meaning of race becomes so great as to have no utility across society.

\section{Talking about race and race talk}

Should we stop talking about race? In a word, no. Denial of race will not bring about the demise of race, rather the cloaking of race will only perpetuate the power of the idea and increase its potential for harm. What we need to do is unpack the term "race" from other confusions about it. Race is not biology, linguistics, nor is it an ethnic grouping. It is not class. Race is not shorthand biology or any other grouping definition. The continued use of race serves no useful purpose. Race is not racism and the end of race classification is not the end of racism. We must recognise, though, that continued belief in real races and the biological or social reality of the race concept provide justification for a racially inequitable status quo and for continued social marginalisation of historically disadvantaged groups (Williams \& Eberhardt, 2008). We can be fairly sure that minor genetic differences that are not correlated to each other, are masked by varying amounts of admixture. Some of these are adaptive with respect to different climates and other environmental circumstances, but they cannot make people act in any particular group-correlated way. Outside of an Us-Them dichotomy, a "group-think" would never be applied. No one invokes the sinister left-handed group as a cause of crime, or that the possession of red hair has any meaning at all, even if we can define such groups with good ontological standing. Race is an historical anachronism, just like the idea of left-handedness or red-headedness being evil.

We cannot stop race talk, and in fact, it is vital we do not stop race talk. When we use it, however, we need to be very specific by what we mean by it. A neologism would help prevent racism but is fraught with difficulties of definition and acceptance. Changing language was successful in the case of gay. A more widespread and accepted redefinition of gendered speech has been a result of a change in attitude to gender equality and anti-sexism drives. A similar effort at de-gendering discourse has had less scientific study than those of biological race studies but has been widely accepted in society. The routine abandonment of the use of gendered diminutives is now widely accepted and previous usage is falling by the wayside as a result of generational change, such as female actor for actress or flight attendant for air hostess. This kind of change has yet to be seen in race discourse even though the rejection of race has a history equal in duration to the equal rights movement. Feminism as a movement, along with the rejection of homophobia and systematic discrimination in either case, is unacceptable today. This can be seen as a result of changes initiated in the social new order growing in the 1960s. These lexical success stories in sexuality and gender are not mirrored in the sphere of race, even though the civil rights movement has a slightly longer history than feminism. 


\section{Conclusion}

In speaking of race today, racial typologies should never be invoked. Race should be spoken about only in an historical context or in terms of current racism. All attempts at othering need to be resisted and any Us-Them divide removed. While many may see such changes as unrealistic or even undesirable, the abandonment of race labels freighted with historical baggage is essential. We cannot just keep the "good parts" of race, because othering has no good side. The unity of humanity is paramount. There should not be further attempts to resurrect racial thinking as a shorthand for something else. If we can unpack all confounding terms, we can show that racial thinking and, certainly, racism are never right. We can stop racism and discrimination, but not by post-racialism. Today still, racism is real even if races are not.

\section{Acknowledgements}

We are grateful to Theresa (Tess) Wilson for help with obtaining and maintaining bibliographic materials. We thank our colleague, Gerhard Maré, for valuable discussions as we developed early drafts of this chapter. We are grateful to many colleagues over the years for discussions of philosophy of taxonomy foremost amongst these being Arnold Kluge, and the California Academy of Sciences "Pizza Munch" philosophy of science forum led by Mike Ghiselin. We extend a special thank you to Mike, a man of supreme erudition, and acknowledge with gratitude his wonderful book, Metaphysics and the Origin of Species (Ghiselin, 1997). He generously donated time to explain principles of taxonomy and their implications to us. The ideas conveyed in this chapter are our responsibility alone. 


\section{References}

Bamshad, M.J.; Wooding, S.; Salisbury, B.A. \& Stephens, J.C. 2004. Deconstructing the relationship between genetics and race. Nature Reviews Genetics, 5. https://doi. org/10.1038/nrg1401

Blumenbach, J.F. 2000. On the natural variety of mankind. In: R. Bernasconi \& T.L. Lott (eds.). The Idea of Race. Indianapolis, IN: Hackett Publishing Company Inc.

Chaplin, G. 2018. An informational taxonomy of race-ideation. In: N.G. Jablonski \& G. Maré (eds.). The Effects of Race. Stellenbosch: African Sun Media.

Croom, A.M. 2011. Slurs. Language Sciences, 33(3). https://doi.org/10.1016/j. langsci.2010.11.005

Croom, A.M. 2013. How to do things with slurs: Studies in the way of derogatory words. Language \& Communication, 33(3). https://doi.org/10.1016/j. langcom.2013.03.008

Eberhardt, J.L. 2005. Imaging race. American Psychologist, 60(2). https://doi. org/10.1037/0003-066X.60.2.181

Eberhardt, J.L. \& Randall, J.L. 1997. The essential notion of race. Psychological Science, 8(3). https://doi. org/10.1111/j.1467-9280.1997.tb00412.x

El-Haj, N.A. 2007. The genetic reinscription of race. Annual Review Of Anthropology, 36(1). https://doi.org/10.1146/annurev. anthro.34.081804.120522

Ghiselin, M.T. 1997. Metaphysics and the Origin of Species. Albany, NY: State University of New York Press.

Graves Jr., J.L. 2003. The Emperor's New Clothes: Biological Theories of Race at the Millennium. New Brusnwick, NJ: Rutgers University Press.

Graves Jr., J.L. 2015. Why the nonexistence of biological races does not mean the nonexistence of racism. American Behavioral Scientist, 59(11). https://doi. org/10.1177/0002764215588810
Jablonski, N.G. 2012a. Living Color: The Biological and Social Meaning of Skin Color. Berkeley, CA: University of California Press.

Jablonski, N.G. 2012b. The struggle to overcome racism. Opinion - The Big Idea. New Scientist. 1 September. https://bit. ly/2thDcoj

Kluge, A.G. \& Wolf, A.J. 1993. Cladistics: What's in a word? Cladistics, 9(2). https://doi.org/10.1111/j.1096-0031. 1993.tb00217.x

Lee, S.S-J.; Mountain, J.L. \& Koenig, B.A. 2001. The meanings of "race" in the new genomics: Implications for health disparities research. Yale Journal of Health Policy, Law, and Ethics, 1. https://bit. ly/374Uof5

Long, J.C. \& Kittles, R.A. 2009a. Human genetic diversity and the nonexistence of biological races. Human Biology, 81(5-6). https://doi.org/10.3378/027.081.0621

Long, J.C.; Li, J. \& Healy, M.E. 2009b. Human DNA sequences: More variation and less race. American Journal of Physical Anthropology, 139(1). https://doi. org/10.1002/ajpa.21011

Maré, G. 2000. Race thinking and thinking about race: Suggestions for terminology. Research Review, 15.

Maré, G. 2011. 'Broken down by race...': Questioning social categories in redress politics. Transformation: Critical Perspectives on Southern Africa, 77. https:// doi.org/10.1353/trn.2011.0037

Relethford, J.H. 2009. Race and global patterns of phenotypic variation. American Journal of Physical Anthropology, 139(1). https:// doi.org/10.1002/ajpa.20900

Samson, J. 2005. Race and Empire. Harlow, UK: Pearson Education Limited.

Soudien, C. 2012. The modern seduction of race: Whither social constructionism? Transformation: Critical Perspectives on Southern Africa, 79. https://doi. org/10.1353/trn.2012.0022 
Soudien, C. 2020. Knowing and being: Living our learning about 'race'. In: N.G. Jablonski (ed.). Persistence of Race. Stellenbosch: African Sun Media.

Spencer, Q. 2009. Is cladistic race a genuine kind? PhD thesis. Stanford, CA: Stanford University.

Spencer, Q. 2015. Philosophy of race meets population genetics. Studies in History and Philosophy of Science Part C: Studies in History and Philosophy of Biological and Biomedical Sciences, 52(Supplement C). https://doi.org/10.1016/j.shpsc.2015.04.003

Sussman, R.W. 2014. The Myth of Race: The Troubling Persistence of an Unscientific Idea. Cambridge, MA: Harvard University Press. https://doi.org/10.4159/ harvard.9780674736160

Thompson, D. 2017. Ice Cube did everyone a favor and schooled Bill Maher on his use of the $\mathrm{N}$-word. Vibe. 10 June. https://bit. ly/2Rtz0JR
UNESCO. 1952. The Race Concept: Results of an Inquiry (The Race Question in Modern Science). Paris: UNESCO.

Wade, N. 2002. Race is seen as real guide to track roots of disease. New York Times [Online]. https://nyti.ms/2uTtU20

Watson, E.C. 2017. Sportswriter uses Notorious B.I.G. lyric containing N-word to comment on LeBron James-Knicks scuffle. Okayplayer. https://bit.ly/36445t8

Williams, M.J. \& Eberhardt, J.L. 2008. Biological conceptions of race and the motivation to cross racial boundaries. Journal of Personality and Social Psychology, 94(6). https://doi.org/10.1037/00223514.94.6.1033 


\section{JPPR@SS VOLUMES IN THE SERIES}
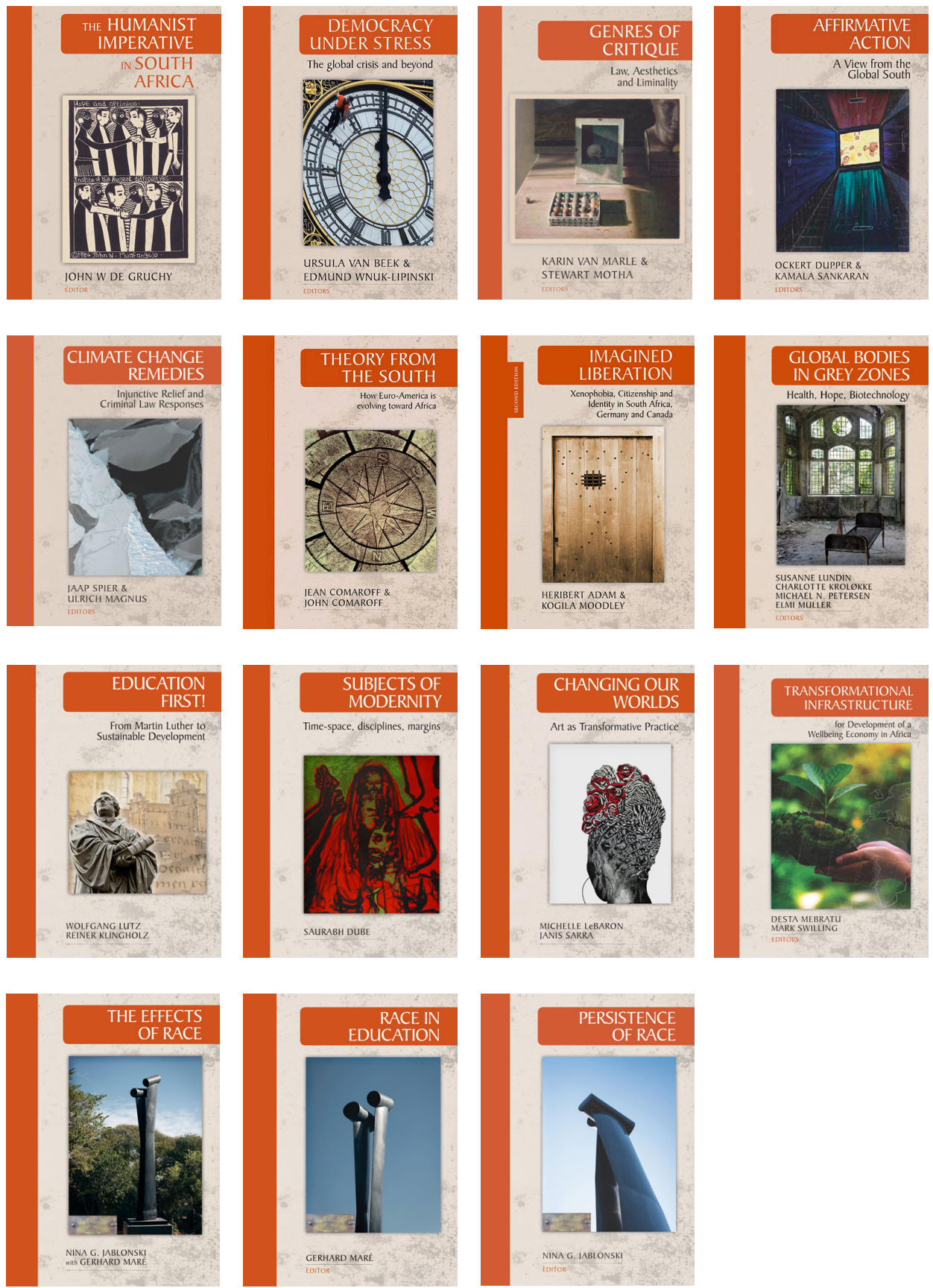